\title{
MUTUALISM SYMBIOSIS BETWEEN PEDESTRIANS AND STREET VENDORS (Case Study: Pedestrian Ways in Dr Radjiman Street Surakarta)
}

\author{
Mila Karmilah $^{1 *}$, Tjoek Surosohadi ${ }^{2}$, Ardiana Yuli Puspitasari ${ }^{3}$, \\ ${ }_{1,2,3}$ Urban and Regional Planning Department, Sultan Agung Islamic University, \\ Jl Raya Kaligawe Km 4 Semarang, INDONESIA \\ *Corresponding author; Email: mila.k@unissula.ac.id/karmilahmila@gmail.com
}

\begin{abstract}
The spatial development of Surakarta is characterized as a transition city between residential and commercial activities. Within the area, the city center develops around the Kasunanan and the Mangkunegaran palaces; here in these two regions the study was conducted. The study conducted in Dr Radjiman Street Solo aims to analyze the characteristics and service facilities for pedestrians on this road segment. Generally speaking, this study is an analytical, descriptive study using qualitative rationalistic approach that focuses on the behavioral approach with behavioral mapping technique. Behavioral mapping approach is used because it is considered as the most suitable and supporting method to identify problems related to the relationship between human and its environment (its spatial system), as well as to make improvements on the design, especially in the commercial area of Dr Radjiman Street. According to this study, the perceptions of street vendors (PKL) are as follows: 1 . Street vendors consider that the sidewalk is a space that they can use as a place for trading; 2 . This is due to the trade location and their residential area is just as far as 1-2 km; 3 . In addition, the merchants also consider that they (and their family) had used the location for more than $>15$ years, thus they unwilling to move away from that location. On the other hand, some factors which become visitor perceptions related to the existence of sidewalks in the Corridor of Dr. Radjiman Street are: 1 . The visitors consider that the existence of street vendors make the pavement becomes such an uncomfort place $(53.3 \%)$, this is because the space for pedestrians become narrowed for $<3$ meters.
\end{abstract}

Keywords: Mutualism symbiosis; pedestrian; street vendors.

\section{INTRODUCTION}

The spatial development of Surakarta is characterized as a transition city between residential and commercial activities. Within the area, the city center develops around the Kasunanan and the Mangkunegaran palaces; here in these two regions the study was conducted.

The condition exists today, there is a trading activity that growing very rapidly in the corridor between Kasunanan and Mangkunegaran palaces. Areal function on this corridor as a trading center (Klewer Market - "Sun Plaza Singosaren" Shopping Center) had caused the parking problems and the rapid growth of street vendor activity on the pavement, results in disruption towards the pedestrians and vehicles circulations. In addition, the conditions of narrow sidewalk and poor pavement also can make pedestrians feel inconvenient given that this corridor is a trade center and there are a lot of pedestrians who use it

In fact, the existence of activity support in public areas (sidewalks and roads) not only disturbs pedestrian activity, but sometimes can also yield such a pleasure for pedestrians, provided that this support activity could share space with pedestrians or in other words the trading equipment of the street vendors do not embrace the entire pedestrian path (Yuli, 2007).

In this work, there will be reviewed several issues connected to perceptions of the street vendors (merchants) and pedestrians related to the degree of ease and safety of the pedestrian area by examining the physical status of pedestrian area as well as the active support that develops and grows in the pedestrian region.

\section{LITERATURE REVIEW}

\section{Pedestrian Ways}

Pedestrian ways are deliberately separated from the circulation and parking area, given that the pedestrian has its own scale that is pedestrian scale. Pedestrian scale is different from vehicle scale; this because the pedestrian scale will get the city environment becomes more detailed, including the pattern of activity (retail), environmental requirements (air, noise, and so on) and circulation safety for the vehicle. Pedestrian is related to: support activities, street furniture, and public transport. 
To date, the physical development of the city for pedestrians are often neglected (Cliff, 2005). In fact, this pedestrian pathway is one essential part of the city design. Pedestrian path not just becomes a portion of the beauty program, but also confirms the trading activity (retail) and amends the city vitality.

Basically, sidewalk is a public place that serves as a means of circulation for pedestrians. In accession, according to Harjoko and Adianto (2011) pedestrian path not just serves as a mean for walking, but also a mean of social interaction among its users. The social interaction is not only done by pedestrians, but also between merchants or other informal economic sectors with pedestrians. Therefore, some aspect needs more care in designing pedestrian paths is how to accommodate the interaction between pedestrians and vehicle lane, as well as debate the suitability of its functions with the needs, physical and psychological comfort.

\section{Perception and behavior}

\section{Perception and Pedestrian Behavior}

Perception according to Kotler (2000: 19) is a process on how people select, organize, and interpret inputs of information to create the whole meaningful image. Perception means also as an analysis of how to integrate our implementation towards things around individuals with the existing impressions or concepts, and then identify the things. As an example, we can see how people who cannot see will be more use his imagination in forming a perception of the object held, touched, and kissed. In relation to the definition of perception according to Kotler, public perception can be defined as a process that is owned by an individual in assessing and interpret objects, events, or relationships gained and finally conclude the information and interpret the whole message contained.

Meanwhile, related to pedestrian behaviour, the provision of walking modes that are safe and comfortable is a crucial need to attract people to use these modes according to their selected destination. People will feel that walking is easier, faster, and cheaper than driving a vehicle (Burton and Mitchell, 2006). According to Burton and Mitchell (2006), there are four factors that affect the length / distance people to walk, namely: time, comfort, availability of vehicles and land-use patterns.

\section{Perception and Behaviour Trader/Informal Sector}

Street vendors (PKL) is a kind of activities from informal commercial sectors (Kuntjoro, 1986). Street vendors are small traders who generally act as distributors of goods and services of the city's economy. From this definition, it can be concluded that street vendors are everyone who does trading and services activity in order to meet the needs of goods consumed by consumers with small / limited funding and usually located in public areas (sidewalks) without any legality.

\section{Activity Support}

Activity support is the correlation between facilities of public areas in the city and all activities regarding the use of urban spaces that support the existence city's public spaces (Haryono, 2007). The concentrated activity in a city is an interconnected system. A dominant activity needs other supported activities. Urban space as an activity support in an urban area can take the form of plaza, pedestrian paths, parking areas, and others.

\section{METHODOLOGY}

The approach required in this study is a method that can reveal the uniqueness of subjective processes, understand meanings, and also reveal phenomena. Therefore, the approach used is qualitative method with naturalistic paradigm.

The analysis method used in this study is qualitative induction which performed in conjunction with the process of data collection. Data is thematic correlation between perception of pedestrian and the street vendors owner, and how they share the space at pedestrian ways. Beside using a qualitative approach this research using a quantitative approach to know the perception of pedestrian that using the pedestrian ways. According Sudjana, 1989 that descriptive research is a research which is attempting to draw an impression or opinion into an information that describes the perception of the subject to the object of research. The data will proceed with descriptive statistics, that is the process of transforming research data in tabular form so that it is easy to be understood and interpreted.

\section{RESULTS AND DISCUSSION}

\section{Analysis of Spatial Dimension of Pedestrian Paths}

The length of pedestrian paths from Klewer Market to Matahari Plasa Singosaren is about 793 meters. The area is divided into three segments to make easier the analysis. Segment one is Klewer Market area, segment two is the area between Klewer Market until Matahari Plasa Singosaren, and segment three is the area near the Matahari Plaza Singosaren. Here is the map of segment distribution in the study area. 

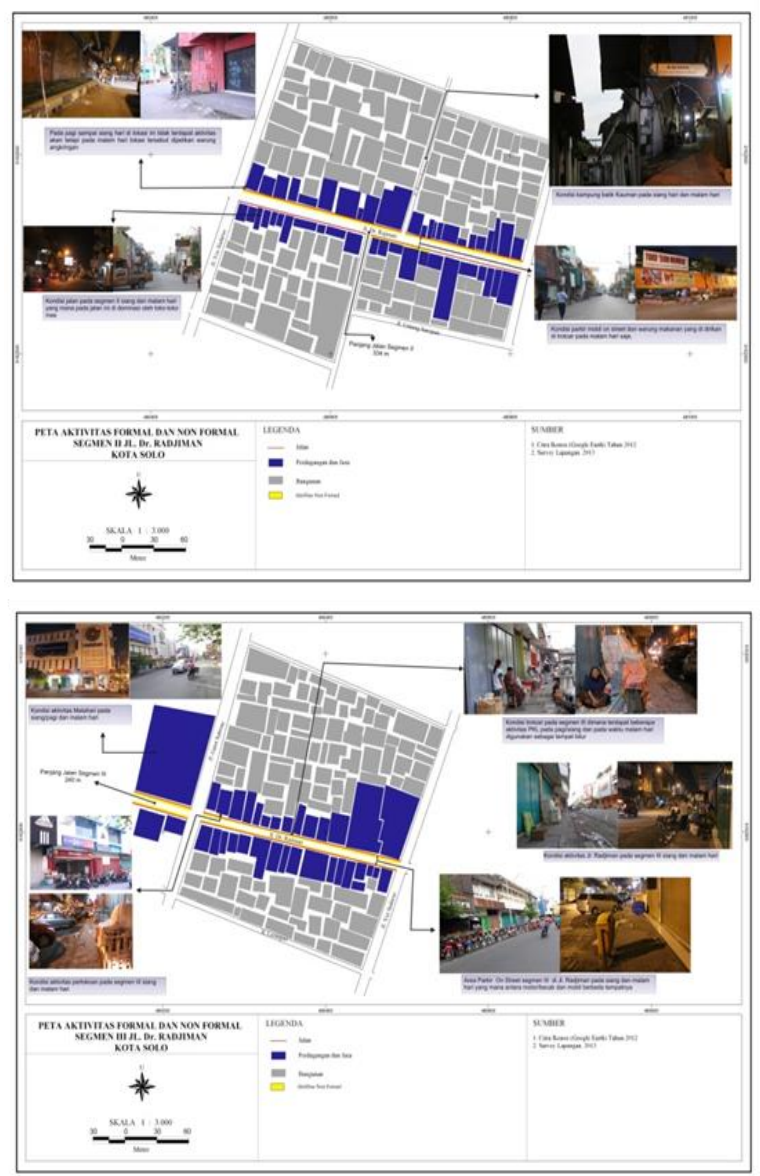

Fig. 1. Differences in Pedestrian Activity that Occurs on Segments II and III.

Figure 1 showed diferences activities in the morning until noon is the formal activities such as trade and services, but at night the activity there are street vendors, parking and a place for the homeless to rest (sleep), from this figure showed that the sreet not only use for economic activity but also for other activity.

The width of the pedestrian path from Klewer Market to Matahari Singosaren Plasa is quite vary. The width for north pedestrian path is averagdely 1.5 meters, while the south path has a width of 1 to 2.5 meters.

Based on the results of questionnaire processing, about $53.33 \%$ of visitors consider that walking in the corridor of J1 Dr. Rajiman feels uncomfortable and their inconvenience mostly due to the presence of street vendors who walk in the pedestrian path thus making pedestrian path becomes narrower.

Related to safety factor, most visitors found that walking in the corridor of Jl Dr. Rajiman is quite safe, while a small number of visitors argue otherwise. The cause of insecurity felt by this small number of visitors is come from the narrow pedestrian paths thus force them to walk on the shoulder path of the road.

\section{Analysis of Support Activities Distribution on Pedestrian Path}

Support Activity or complementary activities on pedestrian paths can take form of street vendors and parking activity. According to the results of field observation, the spatial dimension used by street vendors in the pedestrian path in the study area is averagedly one meter. Most street vendors occupy the pedestrian path (pavement) as their place for trading. While the other small number occupies the body of the road. The width of trading places used by most street vendors is less than three meters square. Street vendors in the study area has many reasons regarding their preference to that location for trading. The most preferred reason by street vendors is because of their current trading location is crowded or frequently visited by buyers.

Half of street vendors in the corridor of Jl Dr. Rajiman have been trading there for more than 15 years. The income earned by street vendors in the study area is quite vary. Most street vendors have daily average income of less than US $\$ 100,000.00$. Others averagedly earn USD $100,000.00$ to USD $300,000.00$ per day. Some of the street vendors have an uncertain income for each day and oftenly they do not earn anything in a day.

Half of street vendors in the corridor of JI Dr. Rajiman were selling food while the other half were selling drinks, cigarettes, convection, as well as offering services (mainly gold-buying services). Most street vendors use a wagon or stroller as their means for trading, while others use the tent stalls, carpet, and basket. In addition, there are also street vendors who use kiosk as their business facilities.

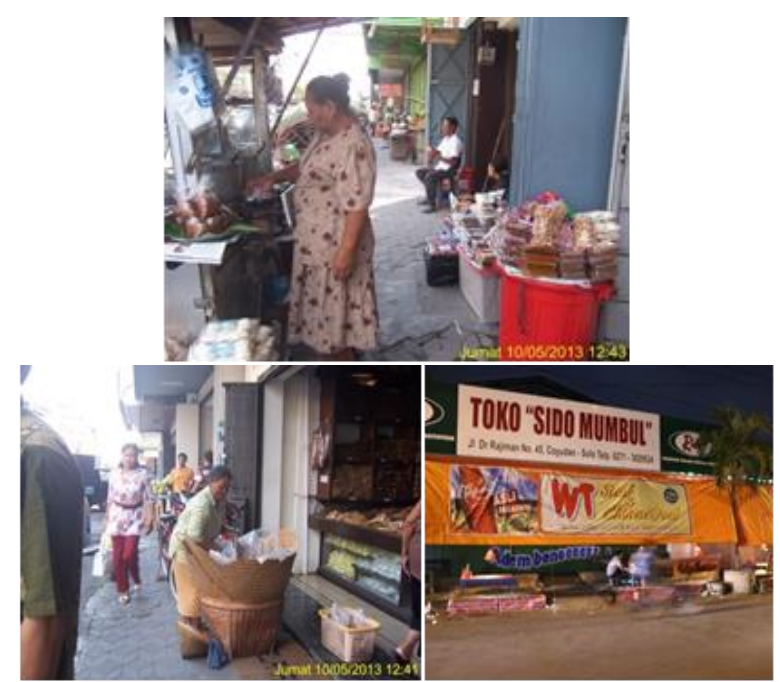

Source: Observation, 2013

Fig. 2. Trading Facilities Used by Street Vendors among others are Wagon, Yoke/Baskets as well as Tent Stalls 


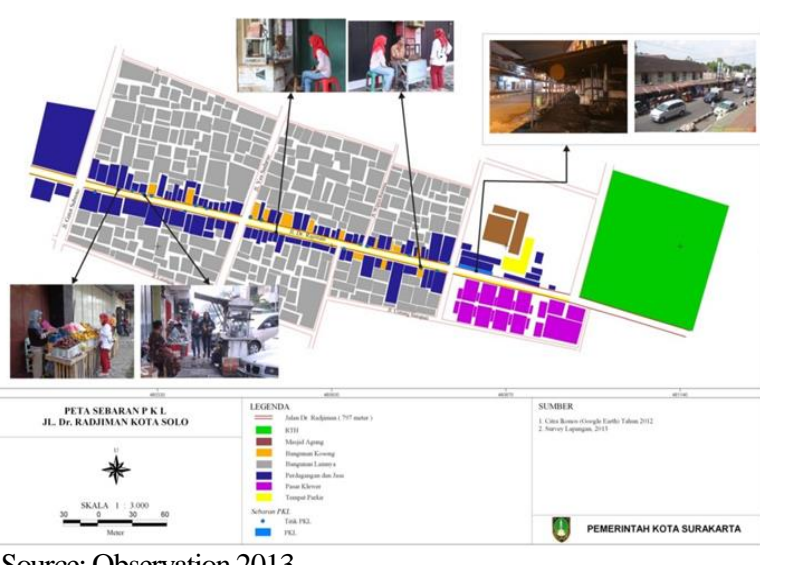

Source: Observation 2013

Fig. 3. Distribution of Street Vendors in the Corridor of Dr. Radjiman Street

Type of grouping for street vendors today are they are mostly in groups with similar, while the rest is mixed with other types of T merchants. Street vendors in the corridor of J1 Dr. Rajiman have various time for trading. Most street vendors start their activity from 08.00 until $17.00 \mathrm{pm}$. There are also some street vendors who trade until late at night until 20:00 to 21:00 pm.

Most visitors come to the study location for shopping, while others come to work and the rest is just taking a walk. Specifically for those who came for shopping, usually they have various reasons why choosing to shop at the location of street vendors in Dr. Rajiman Street. These reasons, among others, due to the cheaper price of goods sold by street vendors than others, a more relaxed atmosphere, as well as its close proximity to their residential area.

The perceived benefits of visitors on the activity of street vendors in the corridor of Dr. Rajiman Street are the location becomes more crowded and the visitors are easily to get their necessities. However, visitors also feel disturbed related to the street vendor's activity. One of the most disturbing matter perceived by visitors is the narrow pedestrian path which make them feel uncomfortable to walk.

Most visitors tend to choose group of street vendors with various kinds of merchandise (mixed) than any group of street vendors of similar merchants. According to them, something that need to be regulated on street vendor's activities is their trading place. Other things need to be regulated are means for trading, types of merchandise, and trading time.

Half of street vendors in the study location want to trade with similar merchants, while the other half wants to trade with merchants of various merchandise (mixed). Most street vendors (approximately 55.17\%) consider that there should be a re-regulation on their trading location today, while the rest regards that there is no need to re-regulate the current trading location. According to most street vendors, thing need to be regulated is the business location. Besides, the other vendors also consider that means of trade, types of merchandise, and time needs to be regulated. Public facilities that need to be added according to the needs of street vendors are trash can, parking area, toilets, electricity, and clean water, sequencely.

Other support activity in the study location is parking activity. Here are parking conditions in the corridor of Dr. Rajiman Street.

Table 1. Parking Condition in Dr Radjiman Street

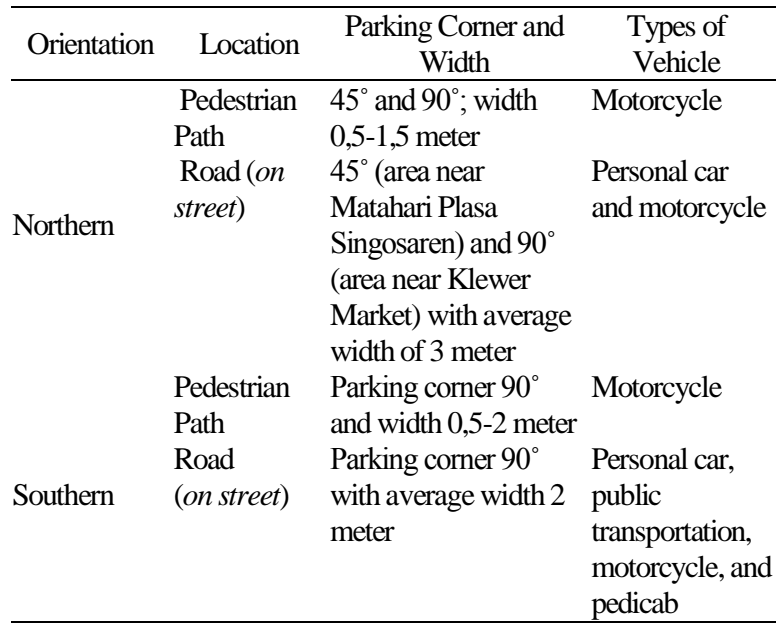

Source: Analysis, 2013

According to most visitors who have activity in the corridors of Dr. Rajiman Street, the parking area for motor vehicle is interfere with the activity of walking. Most visitors regard that the parking lot needs to be re-regulated, as well as other things such as parking corner, types of parked vehicles, and parking time.

\section{Perception and Preference Analysis}

\section{Visitor's Perception and Preference}

Most visitors come to the study location for shopping (60\%), while the rest comes for work and take a walk (40\%). For visitors who specially came for shopping, usually they have various reasons why choosing to shop at the location of street vendors in $\mathrm{Jl}$ Dr. Rajiman. These reasons, among others, due to the cheaper price of goods sold by street vendors than others (64\%), a more relaxed atmosphere, as well as its close proximity to their residential area (36\%).

The visit frequency of visitors to the location is several times a month $(43.33 \%)$ and they prefer walking in the study location (66.67\%) compared to driving a private vehicle or riding a pedicab. 
About $53.33 \%$ of the visitors feel uncomfortable when walking in the corridor of Dr. Rajiman Street and this mostly due to the presence of street vendors who walk in the pedestrian path thus causing pedestrian path becomes narrower. Another reason is the hot weather due to the lack of vegetation along the corridor of Dr. Rajiman Street.

Related to safety factor, most visitors found that walking in the corridor of Dr. Rajiman Street is quite safe, while a small portion of visitors consider otherwise. The insecurity felt by a small number of visitors come from pedestrian paths that so narrow, thus force them to walk on the shoulder of the road.

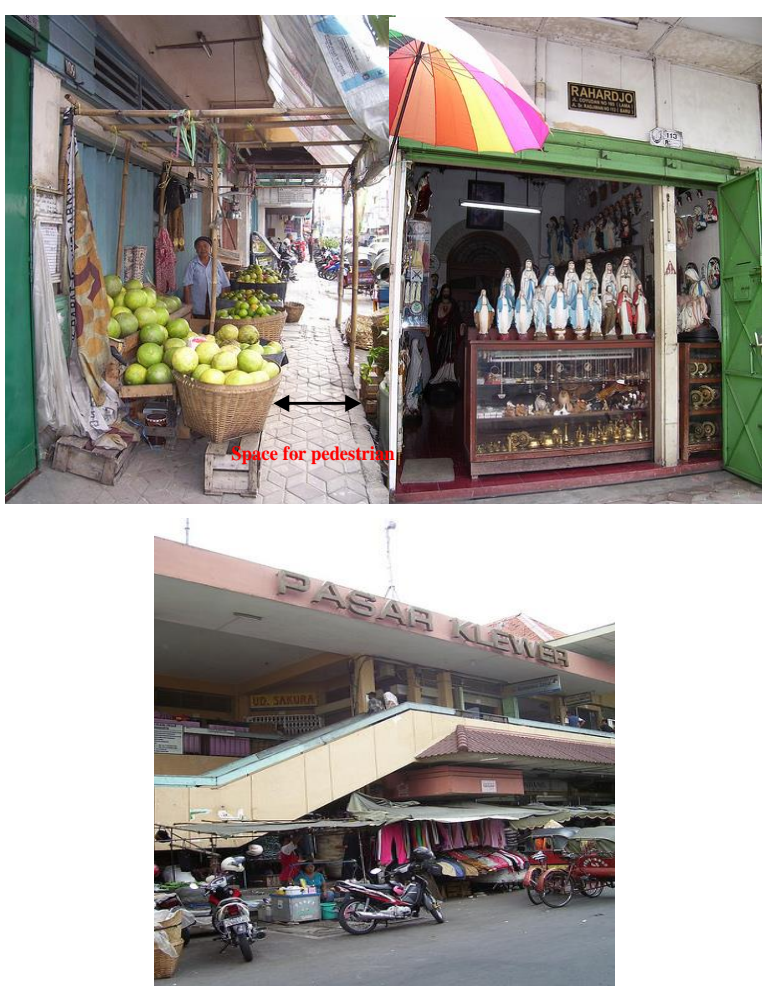

Fig. 4. Support Activities in the Corridor Jl. Radjiman of Klewer Market until the Matahari Deparment Store at Singosaren.

From figure 4, showed that PKL occupies most of the pedestrian path and does not leave room for pedestrian movement. While the buildings along the corridor Jl. Radjiman most of the commercial function with the type of merchandise and services are diversed.

The perceived benefit of visitors with the activity of street vendors in the corridor of Dr. Rajiman Street are the location becomes more crowded and the visitors are easily to get their necessities. However, visitors also feel disturbed related to the street vendor's activity. One of the most disturbing matter perceived by visitors is the narrow pedestrian path which make them feel uncomfortable to walk.

\section{Perception and Preferences of Street Vendors}

From trading period and income earned, street vendors can be characterized as follows: More than $50 \%$ of street vendors in the corridor of Dr. Rajiman Street have been trading for approximately 10-15 years $(70 \%)$. The income earned by street vendors in the study area is vary. Most street vendors earn between $\operatorname{Rp} 100,000.00$ to $\operatorname{Rp} 300,000.00$ per day $(75.86 \%)$. Some of them also have an uncertain income each day and even do not earn anything in a day.

According to $66.67 \%$ of street vendors in the corridor of Dr. Rajiman Street, the condition of pedestrian path (pavement) is still maintained. While the rest regards the contrary. With the existed wide of pedestrian path, most street vendors feel comfortable using the path (73.33\%).

Most street vendors occupy the pedestrian path (pavement) as their place for trading (83.33\%). While the other small number occupies the body of the road. The width of trading places used by most street vendors is less than three meters square $(79.21 \%)$. Street vendors in the study area has many reasons regarding their preference to that location for trading. The most preferred reason by street vendors is because of their current trading location is crowded or frequently visited by buyers.

The distance of street vendor's trading location to where they live is quite diverse. Mostly about $60 \%$ of street vendors only take $1-2 \mathrm{~km}$ to get to their trading location. Most merchants who trade in the corridor of Dr. Rajiman Street (70.37\%) have trading license orom thef Local Government and the rest claimed that they still have no license for trading.

\section{CONCLUSIONS AND SUGGESTIONS}

\section{Conclusions}

From the analysis results and discussion, it can be concluded as follows: Based on the results of questionnaire processing, about $53.33 \%$ of visitors consider that walking in the corridor of Jl Dr. Rajiman feels uncomfortable and their inconvenience mostly due to the presence of street vendors who walk in the pedestrian path thus making pedestrian path becomes narrower.

1. Most street vendors occupy the pedestrian path (pavement) as their place for trading. While the other small number occupies the body of the road. The width of trading places used by most street vendors is less than three meters square. Street vendors in the study area has many reasons 
regarding their preference to that location for trading. The most preferred reason by street vendors is because of their current trading location is crowded or frequently visited by buyers.

2. Most street vendors (approximately 55.17\%) consider that there should be a re-regulation on their trading location today, while the rest regards that there is no need to re-regulate the current trading location. According to most street vendors, thing need to be regulated is the business location. Besides, the other vendors also consider that means of trade, types of merchandise, and time needs to be regulated. Public facilities that need to be added according to the needs of street vendors are trash can, parking area, toilets, electricity, and clean water, sequencely.

3. $81.48 \%$ of visitors argue that the availability of proper lighting is still lacking, as much as $70.37 \%$ of visitors consider that there is no vegetation shade available; about $92.59 \%$ of visitors found that there is a proper and sufficient trash can available; as much as $100 \%$ of visitors think that there is no public telephone available; about $69.23 \%$ of visitors found that there are available signposts with proper conditions; and as much as $66.67 \%$ of visitors regard that toilets with proper conditions are still lacking.

\section{Suggestions}

Based on the conclusions above, there are some suggestions:

1. In order to improve the service (convenience) for pedestrians, problems such as merchandise that is placed on the sidewalk and motorcycle parked on the sidewalk must be removed because the pedestrian facility is build to serve pedestrians, not for trading location of parking area.

2. In order to improve services for new pedestrian in terms of comfort, then the new sidewalks must be equipped with canopies so that pedestrians do not feel heat when they are walking on the new sidewalk at noon.

3. In order to improve safety for new pedestrian, then the new sidewalks need to be equipped with proper lighting so that pedestrians feel safe when walking on the new sidewalk at night.

4. In order to improve safety for new pedestrian in terms of security, the new sidewalks need to be equipped with police stations to minimize crime rate.

5. In order to improve service for pedestrians who interfere with the vehicle parked on the sidewalk, a decisive measure or sanctions should be taken for offenders.
6. There should be further research taken to determine the need for other facilities to improve comfort and safety of pedestrians on the corridors of Dr. Radjiman Street, Surakarta.

\section{ACKNOWLEDGEMENT}

The Author would like to thank Minister of Education for funding the "Hibah Bersaing Scheme" research for two years in Surakarta.

\section{REFERENCES}

Akhma. (2008). Kamus Besar Indonesia-Inggris, Inggris-Indonesia, Gramedia Press, Jakarta.

Burton, E. \& Mitchel, L. (2006). Inclusive Urban Design, Street for Life, Elsevier Ltd, United Kingdom.

Cliff, M. (2005). Urban Design Street and Square, Third Edition, Elsevier, United Kingdom.

Darmawan, E. (2005). Analisa Ruang Publik Arsitektur Kota, Badan Penerbit Universitas Diponegoro, Semarang.

Hakim, R. \& Utomo, H. (2004). Komponen Perancangan Arsitektur Lansekap, Prinsip-Unsur dan Aplikasi Desain, Bumi Aksara, Jakarta.

Harjoko, T.Y \& Adianto, J. (2011). Space Topology: Case Study of Kakilima in the Market of Kebayoran Lama, Jakarta. Journal Procedia Social \& Behavioral Sciences, 36, pp.545- 556.

Haryadi \& Setiawan, B. (2010). Arsitektur Lingkungan dan Perilaku: Pengantar ke Teori, Metodologi dan Aplikasi, Gadjah Mada University Press, Yogjakarta.

Haryono, P. (2011). Sosiologi Kota Untuk Arsitek, Bumi Aksara, Jakarta.

Kotler, P. (2000). Marketing Management, Analysis, Planning, Implementation and Control. Edisi IX. New Jersey; Prentice Hall.

Kuntjoro, J.D. (1986). Kemiskinan di Indonesia, Yayasan Obor, Jakarta.

Muhadjir, N. (2000). Metodologi Penelitian Kualitatif Edisi IV, Rake Sarasin, Yogyakarta.

Moleong, L.J. (2000). Metodologi Penelitian Kualitatif, PT. Remaja Rosdakarya, Bandung.

Sudjana, N. \& Ibrahim. (1989). Penelitian dan Penilaian Pendidikan, Penerbit Sinar Baru, Bandung.

Yuli Puspitasari, A. (2006). Pengaruh Aktivitas PKL terhadap Linkage antara Kraton Kasunanan Pasar Gede Kota Surakarta, Tesis, Program Pasca Sarjana, Magister Teknik Arsitektur, Universitas Diponegoro, Semarang.

Zahnd, M. (1999). Perancangan Kota Secara Terpadu, Kanisius, Yogyakarta. 